\title{
Fostering Sustainable Tourism Development in Merauke through Community-Based Tourism
}

\author{
Machya Astuti Dewi a,1, Sri Issundari ${ }^{\text {b,2, }}$, Iva Rachmawati ${ }^{c, 3}$, Meilan Sugiarto ${ }^{\text {d,4 }}$ \\ a,b,c,d Universitas Pembangunan Nasional Veteran Yogyakarta

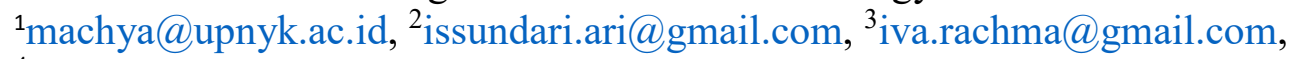 \\ 4msugiarto89@gmail.com
}

\begin{tabular}{l}
\hline Informasi artikel \\
\hline Keywords: \\
sustainable development, \\
tourism, local \\
community, Merauke, \\
community participation
\end{tabular}

ABSTRAK

Merauke is located in the eastern part of Indonesia that is rich of natural and cultural resources potential for tourism. Tourism could be a solution to reduce poverty, especially through community-based tourism. Communities reap economic benefits from tourism industry by the increase of local income, hence the social welfare. On the contrary, poor management may lead the emerging Merauke tourism into environmental ecosystem damage. Such a threat to environmental sustainability outweighs any economic benefits because future generation will suffer from the inherited damaged environment. This article will discuss Merauke community participation in fostering the development of sustainable tourism through community-based tourism, that is maintaining sustainability of the environment and ecosystem while considering local communities sociocultural conditions. In doing so, this study uses a descriptive-qualitative approach. Data was collected from document tracking and interviews with Merauke Regional Government, WWF activists, and community leaders. The findings indicated that local communities supported Merauke tourism by developing entrepreneurship in tourism industry, increasing community social control in protecting the environment and enhancing the role of local customary leaders in supporting the tourism development.

\section{INTRODUCTION}

The current focus of tourism management is the development of sustainable tourism with the aims of benefitting the environment and the economy of local communities, and to have a positive impact on the sociocultural aspects in the region (Nurhasanah, Alvi \& Persada, 2017). Tourism industry should integrate all supporting elements in society, including local culture and the environment so that it remains sustainable and the legacy can be passed on to future generations. Sustainable tourism places society as one of the main instigators. It is the community active participation that revives local resources and uniqueness to stir progress and development in tourism. The higher the community participation to optimize local resources and uniqueness, the faster the tourism will develop.

Merauke tourism relies on its natural wealth as the main commodity so the success and delevopment of the tourism industry is determined by how sustainable the practice is. Therefore, Merauke places great importance in improving and maintaining its sustainability. Not only that the economy, hence social welfare, depends on it but also the ecological balance. The law regulating tourism development in Merauke is Law No. 10 of 2009 about Tourism stating that the wealth of natural resources and historical heritage is the resource and capital to increase social welfare and prosperity; and to achieve the development goal proposed by Merauke Regency Regional Government in 2011-2016 namely "Merauke is the gate 
to intelligent and fit people, the gate to national food, and the gate to welfare and inner peace" (Arifin, 2015). To develop such a sustainable tourism program, all elements of tourism - the government, the society and invested stakeholders - have responsibility for increasing tourism potential and maintaining its sustainability.

The notion of sustainable tourism was initially introduced by the World Commission on Environment and Development (WCAD in Brunland Report 1987), stating that: "Sustainable development is development that meets the needs of present without compromising the ability of future government to meet their own needs". In other words, sustainable development should cater both the current needs to use available resources and the sustainability so that those resources can be passed on to future generations. Then, WTO (1993) proposed development principles that include ecological, sociocultural and economic sustainability. With these principles, resources are expected to last long and are sufficient for both current and generations to come.

The concepts of sustainable tourism development are built upon the notion of sustainable development in general. According to UNWTO, sustainable tourism development is "tourism that takes full account of its current and future economic, social and environmental impacts, addressing the needs of visitors, the industry, the environment and host communities" (UNWTO, 2005). It is a process that gravitates towards the preservation of resources needed for future development, and balances the current and future economic, sociocultural and environmental impacts but still meets the demands in the tourism industry, the environmental industry and the local communities.

A common strategy to develop tourism is to involve communities. Community-based tourism, according to Hausler (2003), is an approach in tourism development that focuses on local communities, both those who are directly and indirectly involved in and affected by the tourism industry. Allowing communities to be involved in the management of tourism is one way to create fair practice and thus provide more benefits for the locals. The community's key roles in sustainable tourism development are explained by Suansri (2003: 12) in the basic communitybased tourism principle, which are: 1) recognizing, supporting and developing community ownership in tourism industry, 2) encouraging community member engagement in every initiative, 3) developing community pride, 4) improving community welfare, 5) ensuring environmental sustainability, 6) maintaining authentic characters and local cultures, 7) assisting learning and cultural exchanges in the community, 8) respecting cultural differences and basic decency, 9) distributing benefits equitably to community members, 10) taking part in determining income distribution in community projects (Suansri, 2003: 12). These key roles put local people both in advantageous and accountable position in managing tourism industry. This idea arises from the fact that tourism industry development often neglects the agency of local communities.

To support the efforts of Merauke government to increase regional development through tourism, it is a must to pay attention to the participation of local communities. The local communities are the central agents in tourism development. They understand local wisdom and will be directly impacted by tourism industry. The involvement of the Merauke communities, especially those around the tourism area, is vital in developing tourism in terms of its economic, sociocultural and environmental aspects. This article will discuss community participation in the practice of sustainable tourism through community-based tourism in Merauke. The rationale of choosing Merauke is because it boasts potential tourism destinations. If managed properly, the tourism industry will improve people's welfare as well as maintain the enviroment's precarious balance. 


\section{METHODOLOGY}

To understand community participation in the development of tourism sector in Merauke this study used a qualitative approach. Data was collected from the results of field observations in some tourism objects in Merauke and interviews with community leaders in Merauke who understood the development of the tourism sector and community involvement. They are the police chief of the Sota Merauke Sector, activist of World Wide Fund (WWF) Merauke, and academics/lecturer from Musamus University Merauke. Data also collected from secondary resources, such as annual reports and relevant journals. All data being categorized according to the relevant topics. The results of the study were then analyzed descriptively.

\section{RESULT AND DISCUSSION The Potency of Merauke}

Merauke is a district in Papua Province covering $46,791.63 \mathrm{~km}^{2}$ of land and $5,089.71 \mathrm{~km}^{2}$ of water (BPS, 2016). Most Merauke region is coastal and swampy lowland, some of which are close to the Arafuru Sea. Some part of Merauke swamp land is part of the Wasur National Park and this has rich flora and fauna.

Adhering to the sustainable concept, tourism industry in Merauke should improve the economic prosperity without neglecting sociocultural values and the environmental conservation. It needs to consider both current and future impacts of the development while also fulfilling the demands in tourism industry and local communities. Merauke's tourism potential lies on its natural wealth that is the coastal areas and swamps with the following potential characteristics.

One of natural potency of Merauke is Onggaya Beach. This beach is located in Onggaya village in the Naukenjeray District, approximately 2 hours 22 minutes drive from Mopah Merauke Airport. This beach is the direct opposite of the Arafura Sea, bordering Australia and Papua New Guinea and is one of the favorite beaches visited by tourists. There are seashells in various shapes and sizes and coconut trees growing along the coast line that make the beach attractive. There are also local people's huts at the seafront (Batbual, http://www. mongabay.co.id/2015/03/30/menjagakampung-onggaya/.

Another beach is Lampu Satu. This beach is located near Merauke city center. It is a fishing village as well as the center of ship crafting. The locals make a living by fishing in the sea and making fishing boats. Near the shoreline are ships being constructed which will be used by fishermen to catch fish in the sea. Every evening fishermen come home from the sea. The fresh fish from the sea are sold to the locals. (Kompas TV, https://www.youtube.com/ watch? $\mathrm{v}=\mathrm{C} 80 \mathrm{fiDUdH0Q}$.

Merauke also rich of beautiful forest: Wasur National Park. This park boasts an amazing beauty because of its biodiversity. Often referred to as Serengeti Papua, this park is the largest productive wetland. This area is usually inundated for 46 months in a year and has become an example of typical wetland in Papua (Kosmaryandi, 2012). Extensive wetlands are unique to the area and this distinguishes Wasur National Park from other national parks in Indonesia. Also, Wasur National Park is a habitat for various flora and fauna with extraordinary ecological, social and cultural wealth and uniqueness that stretches over an area of 413,810 hectares. There are approximately 80 species of mammals, with 34 species being identified and other 32 are endemic to Papua. Wasur National Park is also a haven for 403 species of birds, with 74 of them endemic to Papua and 114 protected (Aji Winara, 2016)

Besides the wealth in fauna, Merauke is also famous for its termite house, or Musamus in local language, which can only be found in Wasur National Park, Merauke. Musamus is built by termites from grass and mud and can reach a height of up to 5 meters. Local residents of Merauke call the termite house Musamus which means a 
"palace" built by termite colonies. The dried grass is glued using termite saliva and it takes a long time to build (Taman Nasional Wasur in https://wisatapapua.wordpress. com/wisata-provinsi-papua/taman-nasionalwasur/.

The coastal area and Wasur National Park offers a unique and distinctive beauty that is different from other regions in Indonesia. If this is managed properly as a tourist destination, the tourism will contribute to the improvement the community welfare. However, poor planning and management remains a problem both in Merauke and in Indonesia in general. As a result, tourism in Merauke has not been optimaly developed and contributed to the regional income. In fact, it might have even inhibited the improvement of community welfare. The communities do not seem to understand the potential benefits of commodifying the natural beauty as a tourism product. Furthermore, if there is a tourism plan, it is often flawed by low awareness of the environmental balance. The rise of sand mining in coastal areas and illegal logging within the Wasur National Park upsets the balance of the nature. For example, within the park, in the area between the coastal villages, namely Kampung Nasem, Merauke District and Dusun Ndalir, Noukenjerai District there are two regions bordered by a river. Both of these regions are on the coast and used to be beautiful coastal villages fenced by green mangrove forests. In the summer, various species of bird from around the world gather to look for food at the beach. Since the 1990s, there have been sand miners in River Ndalir in Kampung Nasem. Beach abrasion is getting worse (Batbual, https://www.mongabay.co.id/2014/04/29/pe nambangan-pasir-marak-mangrove-hilangabrasi-pantai-merauke-mengkhawatirkan/).

The abrasion has damaged roads and bridges. Villages that were once located at a safe distance are becoming increasingly close to the sea. Illegal logging is also pervasive in Wasur National Park. Amin Suprajitno, from the Wasur National Park
Hall claimed that the excavation of sand akin to the one in River Ndalir in Kuler village, Wasur National Park, was expanding. Illegal logging, deforestation and animal poaching are increasing at an alarming rate. The park rangers cannot take an action against the perpetrators of logging and poaching because the area is traditionaly governed by the communal rights (Batbual, https://www.mongabay.co.id/2018/12/12/ta mbang-pasir-menggila-di-merauke-wargakhawatir-bencana/).

The poor tourism development planning remains an issue. It has to be improved in order to increase the welfare of the community and to provide a solution to the threat of environmental damage. One approach is through a community-based system that should create good practice in the management of sustainable tourism.

\section{Community Based Tourism}

Merauke's abundant resources for tourism should be managed in an integrated approach in order for it to thrive in a long term. This means that local communities should become an agent that plays a major role in the development and the sustainability of tourism products. Tourism development in Merauke should be directed with several considerations. On the business side, it has to cater the needs of tourists and practitioners in tourism industry. In terms of social welfare, it should provide opportunities for the local communities to improve their welfare. However, the economic endevour should be taken with ecological considerations in mind. In doing so, local communities should develop their entrepreneurial skills and should be empowered by increasing their social control over the management of the environment and ecosystem. All of these should be supported by local leaders taking up roles in encouraging communities to improve welfare while monitoring the potential impact on the environment.

Tourism should provide economic benefits not only for practitioners in tourism industry but also for the local communities. 
Members of community themselves must seize the opportunity and be more proactive such as by surveying the needs of tourists e.g. souvenirs, cuisine preferences, demands in tour guides and accommodation. This can be accomplished by improving entrepreneurial skills. Local communities can create business opportunities by providing various needs of tourists and this will subsequently impact on the community income. Also, communities can be empowered through capacity building such as training and workshops so that they can take part and be more involved in tourism development.

A strategy proposed by Merauke regional government is to promote tourism through the annual Ndambu cultural festival on Kimaam Island. This festival has been celebrated from generation to generation by the Kimaam Island community and aims to encourage people to continue working and hussling. Ndambu invites the Kimaam Island community groups to compete in many areas of life and encourages people to work hard (Ndambu Bukan Pesta Budaya Biasa https://portal.merauke.go.id/news/ 1837/Ndambu-Bukan-Pesta-Budaya-

Biasa.html).

In addition, the Ministry of Tourism held Cross Border Festival on 3-4 December 2016 at the Sota border between Merauke and Papua New Guinea featuring renowned Reggae artists in Papua (Festival Crossborder Kemenpar di Merauke Berakhir Manis https://indopos.co.id/read/2016/12/ 05/76974/festival-crossborder-kemenpar-dimerauke-berakhir-manis.) Promotional campaigns by the government such as this benefit local communities because their tourism products and services will be more well-known. This also supports the effort to encourage community participation. Entrepreneurial skills should be improved by training, especially in using natural resources responsibly to create a product with added values. Residents in Sota for example, on 24-27 April 2018, were trained to make authentic wooden Merauke souvenirs. The youth in Sota district learned how to make wooden crafts in various shapes and sizes such as key chains, wind chimes, wall decorations and the like. The idea of making wooden handycrafts was originated from the excess supply of timber in Merauke. The material is dry, redundant and scrapped. Then, the youth started to utilize the dry wood to make various crafts. Another example, the women in the Sota area, on 24-15 April 2018, attended culinary training to create food from conveniently available ingredients in Merauke, that was sagoo dodol or sticky cake made from sagoo. The process making the sticky cake is very easy and the final product is profitable so it can provide financial benefits to the local community. Sagoo dodol and wooden souvenirs are expected to become the unique products from the Sota border available in kiosks by the streets throughout the region. From this, it can be concluded that training inspires local communities to develop their entrepreneurial skills and to take business opportunities and profit from the tourism development.

The other effort is improving community social control in preserving the Environment. Tourism relies heavily on the environment so it is crucial to maintain the environmental balance in order to be sustainable. Natural balance is closely related to the community's roles and responsibilities. The common belief is that it is their duty to maintain sustainability so the natural resources can be passed on to future generations. Local communities tend to be more aware of the conditions in their area compared to the outsiders. They will also be directly impacted by the possible natural damage (Keraf, 2010). Considering their vital roles in preserving the environment, joint actions with them should be done through their social control power.

Community social control over the sustainability of the nature is exercised in accordance with local traditions and customs by adhering to the principle of balance. Low public awareness about sustainability impacts on practices that subsequently cause environmental damage, hence jeopardises 
the natural balance. This will then impact on tourism because it relies on the nature and the environment. If community is allowed and encouraged to participate as agents, sustainability is more likely to be achieved.

Merauke traditions are bound to the nature and the natural environment (Kosmaryandi, 2012). The community local wisdom can function as social control since it comes from traditions and culture that has been passed on from generation to generation. For example, there is sasi tradition to guide the utilization of natural resources that has been preserved and practiced by all members and chiefs of the community. Sasi ritual aims to provide opportunities for games or plants to breed. This is done by tying reeds and coconut leaves to a dead tree or a wooden pole. There are swamp sasi, sagoo village sasi, wooden village sasi and fire sasi (Yarman, 2012). The aims of the sasi is to mark the area of tree species, animals, plants or fish which are degraded or are facing a threat of extiction so that people will be more aware of them and take precaution.

Community social control in the environmental sustainability can also be established through Totemism, which is a folk belief that respects animals and native endemic plants in their indigenous territories and regards them as part of the human ancestry. Totemism allows indigenous peoples to utilize natural resources both from their totem clan's area and outside their totem clan's area to fulfil their needs. In case of the latter, people need to ask permission in advance to the totem's owner and treat other clan's plants and animals in accordance with their respective rules. If there is violation, the initial saction is a reprimand. If that does not solve the issue, there will be fines in the form of Wati plant, Kumbili bed making and crop submission e.g. yams and bananas. If the violation is severe, the ultimate punishment is death penalty (Yarman, 2012).

Community social control through the local wisdom sasi, totem and hunting regulations plays a very important role in the development of sustainable tourism in Merauke as it helps protecting the flora and fauna. This uniqueness is what makes Merauke tourist destinations different from those of other regions. Through the community social control, the development of tourim in Merauke is expected to protect the flora and fauna while maintaining its cultural values and local wisdom.

The next effort is improving local adat (customary) leadership in sustainable tourism development. Leadership quality is essential in determining the success of sustainable tourism. Good leadership create a culture and values in sustainable tourism. Local customary leadership will lead to community empowerment because local leaders can direct and mobilize communities towards the common goal that is sustainability. Community is not built from individual actions, but integrated actions with unified goals (Ritzer, 2005). A leader is needed to ensure that community members share common goals and have some sense of camaraderie. Leadership is how to develop and manage the existing resources to achieve desired goals, namely the institutional goals (Maxwell, 1995)

Local customary leadership still holds a very important place in Mearuke society. To illustrate, regional governments need to consult with local customary leaders before gathering local community members in a socialization program (personal interview, April 28, 2019). To avoid social conflicts, traditional leaders play a role in managing local resources. For example, tourism in Sota Merauke sub-district relies on forest eucalyptus oil as a typical local product of Merauke. These products can be found easily in tourist attractions in Merauke. The oil processing uses a simple distillation method. There is only limited distillation equipment and this is unable to match the demands in the communities. The customary leaders make a schedule so that people can take turns using the quipment to produce eucalyptus oil (personal interview, April 21, 2018). In Sota the distillation is scheduled according to the order of the 50 
clans, meaning that there are 50 turns in using the equipment in Sota. Nikodemus Ndiken is a customary leader cum chairman of the Bamuska (village council) who is also a distillator. According to Priyo from World Wild Fund (personal interview, April 20, 2018), a customary leader such as Nikodemus Ndiken controls and manages the eucalyptus oil refinery schedule so that there will not be any conflict.

In addition to resource management, customary leaders also play a role in resolving problems with the natural balance. One example is when the customary leader of Kei clan led the settlement of sasi violation. Kei clan's sea sasi did not allow catching fish in the area opposite of the village for a year because there were major events taking place in the village. The fish in the river needed to be "groomed" for a year. As long as there is a sasi, no one is allowed to catch fish in the area. Similarly, land sasi may not allow coconuts to be taken for sale but are allowed to be taken for domestic consumption. Customary sasi offenders will be tried by the customary leader to be given sanctions. For example, one might be asked to walk around the village carrying coconuts and apologize to all villagers for violating the traditional oaths. The traditional beliefs in Merauke even mention that customary offenders might punishable by death (personal interview, April 28, 2019). In summary, customary leaders' roles are very central, i.e. resolving conflicts that arise in the community fairly and controlling and mobilising communities to maintain the environmental balance.

Sustainable tourism development is a process and a system that can ensure the preservation of natural resources and sociocultural life and provide economic benefits that can be passed on to future generations. Community active participation in local tourism development activities manisfests itself in many forms such as improving entrepreneurial skills, increasing social control in the sustainability management and increasing the role of traditional leaders in tourism development.
These are expected to optimize the tourism development a well as to maintain the sustainability in the long run. Thus, local communities will can be benefitted significantly from the tourism development.

\section{Conclusion}

Developing sustainable tourism is one of the sustainable development programs that aims to ensure the long-term availability of the economic, sociocultural and ecological resources. Merauke, which highlights its tourism on the diversity of its flora and fauna, should plan the tourism development in order to preserve its natural balance. Community-based tourism is an approach that places community members as the main actors who understand the characteristics of the economic, sociocultural and ecological resources needed in developing tourism. Community active participation is expected to contribute to the success of sustainable tourism while complementing the government's programs to increase state revenues outside of mining sectors.

\section{References}

Arifin A., et.al. (2015). Perencanaan Pembangunan dan Pengelolaan Wilayah Pesisir Secara Terpadu Kampung Tomer Distrik Naukenjerai Kab. Merauke Papua. Proyek Pembangunan Masyarakat Pesisir Kabupaten Merauke (CCDP-IFAD) Tahun 2015.

Aronsson, L. (2000). The Development of Sustainable Tourism, London: Continum.

Batbual, A. (2015). Menjaga Kampung Onggaya. http://www.mongabay.co.id/ 2015/03/30/ menjaga-kampung-onggaya/

Batbual, A. (2014). Penambangan Pasir Marak, Mangrove Hilang, Abrasi Pantai Merauke Mengkhawatirkan. https://www. mongabay.co.id/2014/04/29/ penambangan- 
pasir-marak-mangrove-hilang-abrasi-

pantai-merauke-mengkhawatirkan/

Batbual, A. (2018). Tambang Pasir Menggila di Merauke, Warga khawatir Bencana https://www.mongabay.co.id/ 2018/12/12/tambang-pasir-menggila-dimerauke-warga-khawatir-bencana/

Badan Pusat Statistik. (2018). Statistik Indonesia 2018. Jakarta.

Indopos. (2016). Festival Crossborder Kemenpar di Merauke Berakhir Manis https://indopos.co.id/read/2016/12/05/7697 4/festival-crossborder-kemenpar-dimerauke-berakhir-manis

Hausler, N., \& Wolfgang, S. (2003). Training Manual For Community Based Tourism. InWent, Zschoutau.

Nurhasanah, Susana, I., Alvi, N.N., \& Persada, C. (2017). Perwujudan Pariwisata Berkelanjutan Melalui Pemberdayaan Masyarakat Lokal di Pulau Pahawang, Pesawaran, Provinsi Lampung. Jurnal Tata Loka, 19(2), 117-128.

Khrisnamurti, Utami, H., \& Darmawan, R. Dampak Pariwisata Terhadap Lingkungan di Pulau Tidung Kepulauan Seribu. Jurnal Kajian, 21(3), $257-273$.

Keraf, A. S. (2010). Etika Lingkungan Hidup. Jakarta: Kompas.

Kompas TV. Merauke Lampu Satu https://www.youtube.com/watch?v= C80fiDUdH0Q

Kosmaryandi, N. (2012). Taman Nasional Wasur, Mengelola Kawasan Konservasi di Wilayah Masyarakat Adat. Media Konservasi, 17(1), 6-15.

Maxwell, J. C. (1995). Mengembangkan Kepemimpinan di dalam Diri Anda. Jakarta: Binarupa Aksara.
Ndambu Bukan Pesta Budaya Biasa https://portal.merauke.go.id/news/1837/Nda mbu-Bukan-Pesta-Budaya-Biasa.html

Northouse, P. G. (2013). Kepemimpinan: Teori dan Praktik. Jakarta: PT. Indeks.

Palma, A.S.M, Achmad A., \& Dassir, M. Model Kolaborasi Pengelolaan Taman Nasional Wasur Collaboration Models of The Management of Wasur National Park.

Pranita, D. (2016). Membangun Kapabilitas dan Strategi Keberlanjutan untuk Meningkatkan Keunggulan Bersaing Pariwisata Bahari Indonesia. Jurnal Vokasi Indonesia, 4 (2),157-170.

Ritzer, G. (2005). Teori Sosiologi Modern. Jakarta: Prenada Media Jakarta.

Taman Nasional Wasur dalam https://wisatapapua.wordpress.com/ wisataprovinsi-papua/taman-nasional-wasur/

Akses tanggal 30 Agustus 2018

UNWTO http://sdt.unwto.org/content/ about-us-5

Winara, A. (2015). Keragaman Jenis Burung Air di Taman Nasional Wasur Merauke. Jurnal Hutan Tropis (Vol. 4).

Yarman. (2012). Interaksi Masyarakat Suku Asli (Masyarakat Adat) dengan Masyarakat Pendatang dan Implikasinya pada Rancangan Pengelolaan Taman Nasional Wasur. Tesis tidak diterbitkan. Sekolah Pascasarjana Institut Pertanian Bogor.

Sutiarso, M. A., (2018). Pengembangan Pariwisata yang Berkelanjutan melalui Ekowisata, https://www.researchgate.net/ publication/327538432

Suansri, P. (2003). Community Based Tourism Handbook. Thailand: REST Project. 
Subadra, I. N., (2006). Ekowisata Hutan Mangrove dalam Pembangunan Pariwisata Berkelanjutan: Studi Kasus di Mangrove Information Center, Desa Pemagon, Kecamatan Denpasar Selatan, Kota Denpasar. Tesis (S2) Kajian Pariwisata Universitas Udayana.

Zhou, R. et. al. (2015). Pro-Poor Tourism as Approach to Alleviating Poverty: Experiences and Critical Issues. International Conference on Applied Social Science Research (ICASSR).
Personal interviews:

Interview with Ma'ruf Suroto, April 21, 2018.

Interview with Priyo, April 20, 2018.

Interview with Godefridus Samderubun, April 28, 2019. 